\title{
Mutations in Tumor Suppressor Genes: Links between Cancers and Autism Spectrum Disorders?
}

\section{Da-Zhi Liu*}

Department of Neurology and the M.I.N.D. Institute, University of California at Davis, Sacramento, California 95817, USA

Tumor suppressors play critical roles not only to prevent cells in a G0 quiescent state from re-entering the cell cycle for division and proliferation [1,2], but precisely promote the detachment of differentiating neurons from the neuroepithelium and regulate neural differentiation [3]. However, the functional losses in tumor suppressors result in uncontrolled cell proliferation in cancers, and as well as neural differentiation in neurodevelopment disorders, such as autism spectrum disorders (ASDs).

Increasing evidence shows that rapid and excessive increase in head size and circumference in early childhood in children with ASDs in contrast to controls in similar age groups [4-7]. Intriguingly, the overgrowth problems in ASDs seem to be associated with some genetic syndromes involving losses of function in tumor suppressor genes, such as PTEN (phosphatase and tensin homolog), TSC1 or TSC2 (tuberous sclerosis 1 or 2) and NF1 (neurofibromin 1) [7-9]; whereas, the losses of function in those genes can lead to cancers of the breast, prostate, brain, colon, kidney and other organs [10-12]. These suggest the possible links between ASDs and cancers [13].

Recent study demonstrates that Tsc dysfunction results in increased mTOR (mammalian target of rapamycin) activity, and an mTOR inhibitor, rapamycin, whose derivatives have been used to treat cancers prevents the development of autistic behaviors in Tsc-deficient mice [8]. These experimental findings have led to an ongoing phase II clinical trials of RAD001, a rapamycin derivative, in reducing autistic symptoms in patients with tuberous sclerosis complex in Boston Children's Hospital [14]. This strongly supports the links between the two types of diseases, since the same strategy of mTOR inhibition that treats cancers has clinical potential for ASDs therapy as well.

However, there are debates on the links between cancers and ASDs, because some drugs (i.e., thalidomide, valproate) that have antiproliferative effects on cancer cells are reported to elevate autism risk [15]. Thalidomide and valproate are known in cancer therapy for its epigenetic effects as a histone deacetylase inhibitor, but it is not clear yet of the mechanism by which they elevate autism risk [15].

Although mutations in tumor suppressor genes may link cancers with ASDs, little are known about why mutations in those genes sometimes lead to ASDs and/or cancers and other times do not. It is likely that the genetic inclination associated with mutations in tumor suppressor genes toward cancers and ASDs may requiresome "triggers", such as environmental pollutants, to cause symptoms.

\section{References}

1. Liu DZ, Ander BP (2012) Cell cycle inhibition without disruption of neurogenesis is a strategy for treatment of aberrant cell cycle diseases: an update. ScientificWorldJournal 2012: 491737.

2. Liu DZ, Ander BP, Tian Y, Stamova B, Jickling GC, et al. (2012) Integrated analysis of mRNA and microRNA expression in mature neurons, neural progenitor cells and neuroblastoma cells. Gene 495: 120-127.

3. Rousso DL, Pearson CA, Gaber ZB, Miquelajauregui A, Li S, et al. (2012) Foxpmediated suppression of $\mathrm{N}$-cadherin regulates neuroepithelial character and progenitor maintenance in the CNS. Neuron 74: 314-330.
4. Courchesne E, Carper R, Akshoomoff N (2003) Evidence of brain overgrowth in the first year of life in autism. JAMA 290: 337-344.

5. Hazlett HC, Poe M, Gerig G, Smith RG, Provenzale J, et al. (2005) Magnetic resonance imaging and head circumference study of brain size in autism: birth through age 2 years. Arch Gen Psychiatry 62: 1366-1376.

6. Courchesne E, Karns CM, Davis HR, Ziccardi R, Carper RA, et al. (2001) Unusual brain growth patterns in early life in patients with autistic disorder: an MRI study. Neurology 57: 245-254.

7. Butler MG, Dasouki MJ, Zhou XP, Talebizadeh Z, Brown M, et al. (2005) Subse of individuals with autism spectrum disorders and extreme macrocephaly associated with germline PTEN tumour suppressor gene mutations. J Med Genet 42: 318-321.

8. Tsai PT, Hull C, Chu Y, Greene-Colozzi E, Sadowski AR, et al. (2012) Autisticlike behaviour and cerebellar dysfunction in Purkinje cell Tsc1 mutant mice. Nature 488: 647-651.

9. Mbarek O, Marouillat S, Martineau J, Barthélémy C, Müh JP, et al. (1999) Association study of the NF1 gene and autistic disorder. Am J Med Genet 88: 729-732.

10. Phuah SY, Looi LM, Hassan N, Rhodes A, Dean S, et al. (2012) Triple-negative breast cancer and PTEN (phosphatase and tensin homologue) loss are predictors of BRCA1 germline mutations in women with early-onset and familial breast cancer, but not in women with isolated late-onset breast cancer. Breast Cancer Res 14: R142.

11. Li J, Yen C, Liaw D, Podsypanina K, Bose S, et al. (1997) PTEN, a putative protein tyrosine phosphatase gene mutated in human brain, breast, and prostate cancer. Science 275: 1943-1947.

12. Mehta MS, Vazquez A, Kulkarni DA, Kerrigan JE, Atwal G, et al. (2011) Polymorphic variants in TSC1 and TSC2 and their association with breast cancer phenotypes. Breast Cancer Res Treat 125: 861-868.

13. Crespi B (2011) Autism and cancer risk. Autism Res 4: 302-310.

14. Sahin M (2013) Trial of RAD001 and Neurocognition in Tuberous Sclerosis Complex (TSC).

15. Ward CS (2013) Autism's cancer connection: The anti-proliferation hypothesis and why it may matter. Med Hypotheses.
*Corresponding author: Da-Zhi Liu, Department of Neurology and the M.I.N.D. Institute, University of California at Davis, Sacramento, California 95817, USA, Tel: +1-916-703-0383; E mail: dzliu@ucdavis.edu

Received December 12, 2013; Accepted December 12, 2013; Published December 14, 2013

Citation: Liu DZ (2013) Mutations in Tumor Suppressor Genes: Links between Cancers and Autism Spectrum Disorders? J Cytol Histol 5: e109. doi:10.4172/21577099.1000e109

Copyright: (C) 2013 Liu DZ. This is an open-access article distributed under the terms of the Creative Commons Attribution License, which permits unrestricted use, distribution, and reproduction in any medium, provided the original author and source are credited. 